\title{
The Bulgarian Military: In Search of New Alignments
}

\author{
Stephan E. Nikolov*
}

At the beginning of its democratization process, Bulgaria inherited armed forces that had been shaped to serve the Soviet Union's military doctrine. There was no doubt that, among all the Warsaw Pact members, Bulgaria was the most loyal and reliable. ${ }^{1}$ In September 1945, in a matter of days, the Bulgarian armed forces transferred their allegiance from the still too young Tsar (and from being an ally of Nazi Germany) to a new world power-Stalin's Russia. The same troops that, until a few days before, were fighting Yugoslav partisans under Tito and their Greek counterparts now had to cooperate with them.

This generally confusing situation, where enemies suddenly became allies and now had to cooperate on the front line, caused many problems and internal confusion, as could be expected. However, it was the beginning of a thorough purge within the military. Regular troops were joined by units of the Bulgarian partisans, and each unit, from the platoon level and up, received (as was the case in the Red Army) a deputy commander for political affairs - or a political commissar — with wide-ranging orders to control the commander. Under this political pressure and the tension of battle, troops were shaped to become the new armed forces of Communist Bulgaria. Until 1947-48, practically all military positions were filled with people loyal to the Communist regime-Soviet-trained officers of Bulgarian background, or guerilla cadres, who were rapidly retrained in Soviet military academies. Only a few old-timers were relieved of their command functions and reassigned to the military schools and academies. Even those captains who had helped the Communists to seize power, and were elevated to the rank of general, were expelled from active duty. Many officers, even those from the last classes to graduate from the military schools, were sentenced and, if they succeeded in evading capital punishment or death in the labor camps, served long prison terms and were denied the possibility of continuing their profession. Moreover, the purges reached even the glorified guerilla commanders-such as Generals Slavcho Trunski, Dencho Znepolski, and many others - on such grounds as pro-Yugoslav sympathies, or affiliation to resistance groups that were considered to be not quite submissive enough to the Moscow-based Communist leadership.

When in 1954 a relatively obscure local activist, Todor Zhivkov, came to power on a wave of anti-Stalinist enthusiasm, and especially after he established his position between 1956-62, his guerilla unit, Chavdar, became the main reservoir for cadres for

* Dr. Stephan E. Nikolov is a Senior Research Assistant at the Institute of Sociology in Sofia, Bulgaria.

1 See, for more details, Stephan Ashley, "Bulgaria: Between Loyalty and Nationalism," in The Warsaw Pact and the Balkans: Moscow's Southern Flank, ed. Jonathan Eyal (New York: St. Martin's Press, 1989), 109-53; Daniel N. Nelson, "Political Dynamics and the Bulgarian Military," Berichte des Bundesinstituts für ostwissentschaftlisches und internationale Studien 43 (July 1990). 
both high positions in the civilian and military fields. Blessed by his tutor, the Soviet leader Khruschev, Zhivkov was able even to replace former Soviet Army officers like Generals Mikhaylov, Panchevski, Kinov, and many others, with persons from the internal anti-fascist resistance, whose first loyalty was to him personally. Thus, Todor Zhivkov, who was removed as leader of the Bulgarian Communist Party and head of state only in November 1989, created a military command structure that was probably the most devoted to the Communist ideal and completely trustworthy within the Warsaw Pact. A former Chavdar partisan unit commander, General Dobri Djurov, who served as Minister of Defense from 1962 to 1990, was the longest serving official in this position in contemporary Europe.

Under Djurov, the military became second only to the secret services in the intensity of screening for avoiding politically, class, and ideologically "unreliable" candidates. $^{2}$ Applicants' backgrounds were even more important than their scores on special examinations and physical fitness tests for their enrollment as cadets. Even after the military profession had become a less attractive for youngsters, and primarily rural boys were going to military schools (with the possible exception of the air force and navy), mainly because they could not compete for the civilian universities, these restrictions were kept firmly in place. An anonymous letter accusing even a remote relative of affiliation with a non-Communist organization in the past was enough to dismiss an otherwise promising young cadet from the school. The general pattern was that a successful cadet had to be the son of a guerrilla fighter, or at least a helper of the Communist insurgents - in the best case, a member of the Communist Party in good standing (i.e., unaffected by the periodical purges, even if he was readmitted later) and himself an active member of the Communist Youth (Komsomol) or of the Communist Party itself.

This close political grip continued not only during the cadet's years at the military academy, but continued throughout his entire military career. Every military unit had Young Communist and Communist Party organizations, and their bureaus kept close watch on each officer, having the last word on his promotions or acceptance to higher military courses. An occasional "unacceptable" expression of opinion on the party line or international events, or a politically incorrect joke, could ruin one's career. Military officers were required to be, first of all, active Communist Party members - non-affiliated men were very rare among the officers, and almost nonexistent among the senior military personnel. Even the puppet "allied" Agrarian Party was not accepted within the barracks, even to keep a balance between patriotism and a more explicitly pro-Soviet stance. At the top of the power structure, in addition to the main political directorate of the armed forces, political purity and loyalty was observed also by the so-called "Military Administration Department" on the Central Committee of the Communist Party, headed by an active-duty general.

2 Stephan E. Nikolov, "The Bulgarian Armed Forces in Transition," Jane's Intelligence Review (April 1995): 152-53. 


\section{Toward a Thorough Reform of the Military}

The first measures taken in 1990 were to remove Party organizations from the barracks. The first democratically elected president, former dissident Zhelyo Zhelev, started his term with a decree for the de-politicization of certain categories of state employees, among them the military. This step was met with some opposition, but was generally accepted. Later, the Warsaw Pact, which had already become obsolete, was dissolved. All this preceded even more radical measures in the process of military reform that put Bulgaria on its way toward membership in the Partnership for Peace, and later to full NATO membership, which was achieved in May 2004. By and large, the painful reforms began only in 1997 with the adoption of a relevant package of legislation. $^{3}$

An important part of the military reform was, first, the restructuring and re-deployment of the Bulgarian armed forces, and, second, a substantial reduction in their size, shape, and purpose. Molded strictly under the Soviet model — and serving Soviet military strategy in the Southeast European theater ${ }^{4}$-Bulgarian combat units were heavily concentrated along the southern border with its likely opponents, NATO members Greece and Turkey. Inside the country, and especially in northern Bulgaria, were allocated mainly rear services, military schools, and other auxiliary units. In case of mass mobilization, it was envisaged that within a couple of days the standing military- of anywhere between 105,000 and 120,000 men-would be enhanced to a million or more. This made up a seemingly powerful military - men in uniform and military vehicles, including many armored vehicles, were highly visible - but one that had a cumbersome chain of command and was leaving much to be desired in terms of speed of deployment. Most of these units were closed to go to a battalion-brigade organization, resulting in a far more flexible and mobile force.

There is still a lot to be done, especially with respect to out-of-date armament and equipment, and the professionalization of the forces, but at least half of the painful changes are already history. Military personnel were reduced to 45,000, and the formerly inverted pyramid of commanding personnel, with too many senior officers, is becoming more normalized. ${ }^{5}$ This was done at a high social cost-thousands of military officers failed to reach the term of service required for to receive a full military pension, and had to join the army of the unemployed (which often already included their wives), and the closure of garrisons deprived some already economically depressed locations of their only, or most important, source of income.

3 Nansen Behar, "Civil-Military Relations and the New Defense and Security Legislation in Bulgaria," in Legal Framing of the Democratic Control of Armed Forces and the Security Sector: Norms and Reality/es, ed. Biljana Vankovska (Geneva: Geneva Centre for the Democratic Control of the Armed Forces/Belgrade: Centre for Civil-Military Relations, 2001), $125-36$.

4 It was provided that, in case of war, Bulgarian troops were to be put under the command of the Kiev military okrug of the Soviet Army.

5 Bulgarska Armiya Daily (BA), 22 January 2004, Nr. 15774. 
Once again, the Bulgarian Army had to start practically from scratch, leaving behind almost everything that had been accumulated in decades of training, building, and drilling. This was the third time during the turbulent twentieth century that such a task occurred (the first was after World War I, and the second after Word War II). If in the 1920 s there had been abundant equipment and well-trained cadres that had to be transferred into other fields of social activity, and in the late 1940s new rulers mercilessly replaced all military personnel, both senior and junior, with completely new forces, even literally exterminating those who appeared to be opposed to the new measures, this time the situation was vastly different. In no way could this new democratic regime completely replace the inherited personnel, with their established way of thinking and outlook - personnel that had been selected and prepared for totally different purposes. The normal process of development of current cadets and lieutenants into colonels and generals takes many years; it cannot be accelerated without much risk and failure. At the same time, much armament and equipment already needed replacement due to its age and incompatibility with modern methods of warfare, while a deep economic crisis continues to prevent new procurements for years to come.

The lack of resources to procure new equipment led some observers to criticize the process of military reform for being reduced to cutbacks of personnel, equipment, and garrisons. In addition, some of the restructuring efforts have apparently been in vain, since the current size of 45,000 corresponds to one corps, according to NATO standards. ${ }^{6}$ This situation is the cause of infinite perplexity and all too often introduces discord between those in the civilian and military leadership of the armed forces who are clearly still not sufficiently clear about their frames of responsibility. For example, for a long time the 45,000-strong military was considered the bottom line of the personnel reductions, but Chief of General Staff General Kolev even called it "the sanitary minimum" under current circumstances and conditions in Bulgaria. ${ }^{7}$ And, while Minister of Defense Svinarov was assuring the nation that the era of reductions, dismissals, and destruction was already over, and was to be replaced by an era of rebuilding, ${ }^{8}$ it now appears that a target of 39,000 is the next goal to be pursued. ${ }^{9}$

\section{New Roles for the Military}

One of the important new experiences that accompanied these changes and largely helped to accelerate reform was the decision to offer Bulgarian military personnel for participation in UN and NATO-led peacekeeping forces. Bulgaria had never engaged in such a practice in the past, and this decision marked a significant shift in how the

6 Panayot Angarev, "Army - Reduced, but not Reformed," Dnevnik Daily, 22 October 2002.

7 Gen. N. Kolev, Interview, $B A$, 2 September 2003, Nr. 15677; compare also Gen. N. Kolev, Interview, $B A, 3$ February 2004, Nr. 15782.

8 Minister N. Svinarov, Interview, $B A, 13$ February 2004, Nr. 15780: "We do not speak any more about reductions, but rebuilding"; Minister N. Svinarov, Interview, BA, 2 March 2002, Nr. 15802: "There Will Be No More Reductions in the Bulgarian Armed Forces."

9 “39,000 Troops until 2015,” in Duma Daily, 22 July 2004, Nr. 168 (4269). 
military was viewed. ${ }^{10}$ In general during this period, of the former Warsaw Pact nations, only Polish military personnel were allowed to participate in UN-sponsored peacekeeping missions, especially as observers at the demarcation lines between North and South Vietnam, in Cyprus, Lebanon, Gaza, etc. The first Bulgarian military observers were sent in 1991 to such remote places as Tajikistan, Ethiopia, and Eritrea, and despite their lack of proper experience, their performance was considered fair and effective. President Zhelev was eager to send Bulgarian medical and engineering units to join the coalition for the first Persian Gulf war, but time appeared to be insufficient to prepare them-before Bulgaria was able to dispatch its soldiers, warfare was substantially finished, with Iraqi troops having been expelled from Kuwait. The first ever large mission of Bulgarian peacekeepers was to Cambodia in 1992-93, where their assignment was to secure the organization of legitimate and fair elections after decades of civil war and the bizarre rule of the Khmer Rouge. There was nobody in Bulgaria then with any experience in such a mission, which was, moreover, in a distant, exotic, and unfamiliar country. In addition, Bulgarians were designated to reside in areas far from the big cities, in the jungle, and where residues of the Khmer Rouge existed. Leaving aside all bad occurrences, the Cambodian experience was bitter and difficult, but it was also crucial for the future prospects of Bulgarian participation in peacekeeping and peace-enforcement efforts all over the world. After the completion of that mission, both Bulgarian authorities and the UN determined that Bulgarian peacekeepers in Cambodia had successfully performed over 70 percent of the tasks with which they had been charged, especially in the fields of preparation for the elections and disarmament of the population. The Bulgarian military was praised by the UN authorities, and decorated with medals.

On the basis of this experience, the former Second Bulgarian Army was transformed into the Rapid Deployment (later Operative) Forces, and several of its units became the first units to be largely professionalized (e.g., filled with voluntary forces, not conscripts), deserving to be considered as fully prepared for various combat duties according to modern standards, and as the main force to be deployed on the next international peacekeeping mission. This occurred under the command of one of the Cambodian battalion's commanders, Colonel (later Brigadier General) Stefan Nikolov.

Reconsidering their experience, it was concluded that participants in such missions should not only be carefully selected from the best performing among the professional soldiers serving in the elite units; it was also found that, despite, the shortages in sup-

${ }^{10}$ During the Communist period, sending troops abroad even for military exercises was very rare. Bulgaria's geographical location, which required passage through territories of countries not part of the Warsaw Pact, or through Ceausescu's Romania, which was restricted to participating in a minimal level of Warsaw Pact-related activities, prevented Bulgaria from participating even in joint military exercises. In August 1968, however, a Bulgarian regiment was sent into Czechoslovakia - along with the troops of the USSR, East Germany, Poland, and Hungary - to participate in crushing the Prague Spring. At least one Bulgarian soldier was killed in this mission, which can not be considered a source of pride.

* The coincidence with the name of the author of this article is purely incidental. 
ply for the armed forces in general, special attention needed to be paid to obtaining better equipment - armament, vehicles and other tools, but also clothes and shoes-for missions abroad. It was also recommended that extreme climatic and geographical conditions for deployment should be avoided, if possible.

After the Dayton Agreements, Bulgarian troops - mainly convoys, guards, and engineering specialists - were deployed under German or Dutch command in Bosnia (at the Butmir base near Sarajevo), and later on policing and engineering units in Kosovo. There were some anxieties about arousing hostility due to old Balkan prejudices, ${ }^{11}$ but they proved to be groundless - the Bulgarians, with their professional abilities and discipline, and also their better understanding of the language and mentality of the Balkan peoples, proved to be a useful part of the Bosnia and Kosovo peace enforcement efforts.

One method for overcoming those "ghosts from the past," as a Western author called the Balkan reality of centuries of accrued distrust, prejudice, and conflict, was the initiative for creating a Balkan multinational brigade. Initially it seemed like either a bad joke or a daydream: to gather in one place people with deep mutual prejudices and suspicion, of different faiths, who had been considered to be enemies almost until yesterday-Turks and Bulgarians, or Macedonians and Albanians, to mention only few of the challenges - and, moreover, to put guns in their hands! Nevertheless, the project appeared to be workable. The site for the first term of the rotating deployment was the second-largest Bulgarian city, Plovdiv, and barracks were renovated according to NATO standards to accommodate mechanized battalions from Bulgaria, Greece, Italy, Romania, and Turkey, and infantry companies from Macedonia and Albania, which were placed under the command initially of a Turkish, ${ }^{12}$ and later of a Greek general. Within the first four years, Balkan multinational forces completed a thorough training regimen, took part in a series of NATO-sponsored military exercises, and-probably the most important - proved that the initial fears had been pointless, and that Balkan countries could offer a capable, highly effective multinational force that could deal in the future with managing certain potential conflicts, both internal and external. In the meantime, however, it was (probably wisely) decided that it would be premature to use soldiers from the Multinational Balkan Force for the task that force is expected to deal with in the future - deployment in the conflict zone of a Balkan state. In 2002, the force was successfully re-deployed to its next designated location, the port city Constanta on the Black Sea. It might be expected that within a few years it will reach its

11 A curious confusion, revealing Balkan burdens from the distant past, occurred when, during a visit in Germany, Bulgarian Minister of Defense Svinarov mentioned that Bulgarian troops may replace withdrawing German units in Macedonia. In Skopje, this unveiled bad memories from WWII, when Bulgarians administered most of current territory of the Republic under the German auspices, and ignited furious debate even in the Parliament near Vardar. This was a reminder of how sensitive this issue is when it involves unsolved problems from the past that are not so easy to be forgotten or buried.

12 The first commander of the force, Gen. Zorlu from Turkey, later had a successful mandate as chief commanding officer of the multinational troops in Afghanistan. 
full strength of a brigade, with between 2,500 and 4,000 military personnel, according to the concrete tasks, and with possible future inclusion of Croat and Serb units.

The next test for the abilities of the Bulgarian peacekeepers was the deployment of a chemical disinfecting unit in Kabul, Afghanistan. Since it included a hygiene bath facility, it became source of mockery in the Bulgarian media, which depicted its members as "bath-house attendants" for the multinational force there. This unit, however, had special and important tasks in the war-torn country, including escort missions, which were performed successfully. This made it possible for the multinational command to make an invitation to the Bulgarian Ministry of Defense to augment the Bulgarian presence in Afghanistan as a part of the Phoenix Multinational Force. Bulgarian military experts were assigned to execute responsible tasks in the building and training of the new Afghan National Army, including the repair of Soviet-made military equipment (armored vehicles, etc.). A staff of eighteen to twenty officers and NCOs from the $13^{\text {th }}$ armored brigade from Sliven, Bulgaria is permanently delegated to assist Afghan colleagues in the training of drivers (including drivers of tanks), maintenance and repair of the equipment, and drill in weaponry and tactics. An indication of their performance was the invitation to increase the current 55-strong Bulgarian military contingent in Afghanistan by 200 more. Bulgaria was given the important responsibility of taking over security at the Kabul airport. Bulgarian Minister of Defense Svinarov recently proposed a Balkan multinational force brigade, which was just licensed as combat ready, to be deployed in Afghanistan.

\section{Iraqi Mission}

In 2003, the Bulgarian contribution to peacekeeping efforts reached its apex with the invitation to join the multinational peace enforcement force in Iraq. A 480-500 strong battalion was placed in the Shiite center of Karbala in central Iraq under the command of Polish staff. Thus, as of February 2004, Bulgarian deployment in missions abroad totaled 814 military men and women on three continents: Europe, Africa, and Asia. Such a number of staff deployed abroad seems quite large for a 45,000-strong military; moreover, it surpasses similar contingents of much richer and more experienced countries, like Norway, Belgium, Denmark, the Czech Republic, and Portugal.

Though seemingly distant and alien, Iraq is probably among the possibly natural targets of Bulgaria's own interests and strategic objectives. Bulgaria has a long record of good relations, including economic cooperation, with Iraq, regardless of the political regimes of the two countries. Many power stations, irrigation works, and other infrastructural facilities in Iraq — among them the Baghdad international airport — were built by Bulgarian specialists and workers, and according to Bulgarian design. Thousands of Iraqi professionals, including some members of the current provisional government, completed their education in Bulgaria. During the years of the Saddam regime, Bulgaria hosted a not so negligible Iraqi emigrant community. And, last but not least, the previous Iraqi regime had an unpaid debt to Bulgaria of about US\$3 billion, representing the greatest share of the foreign liabilities owed to Bulgaria, and which-under 
the current circumstances of a severe economic crisis and Bulgaria's own debts to foreign countries and international institutions - our country hopes to recover one day.

On 22 May 2003, the Bulgarian government decided to take part in the Iraqi mission, sending an infantry battalion. Soon it became clear that the Bulgarian battalion would be attached to the Polish brigade, which was assigned a zone of responsibility in central Iraq. A week later, the Bulgarian parliament approved (by a margin of 160 votes to 4) the decision to permit the participation of the Republic of Bulgaria in the fourth phase of the operation in Iraq, called "Stabilization and Development," which includes sending an infantry battalion of up to 500 personnel. It was reaffirmed that this task force would be filled by volunteers, and the city of Karbala-a holy place for Shiite Muslims - was for the first time mentioned as a future base for the Bulgarian troops. On June 8, the Prime Minister, Simeon Sakskoburggotski, visited Karlovo to review the preparation of the battalion, staffed with 413 servicemen, and Minister of Defense issued an order for further enrollment of the necessary personnel, specifying the assignments of the required officers, NCOs, and professional soldiers. On June 20 military team from Bulgaria visited Babylon and Karbala to inspect future sites for deployment, and between June 17-24 the unit passed certification. On July 18, President Purvanov met with the Minister of Defense and the Chief of General Staff, General Kolev, to review the preparation and logistics process. On July 25 in Warsaw a memorandum on the Bulgarian partnership in the operation in Iraq was signed, and on August 11 the first group of rangers departed for the mission in Iraq from Krumovo airfield near Plovdiv.

On August 26, Lt. Col. Marinov was given the position of military governor of Karbala by his U.S. predecessor. Bulgarian troops were quartered at two bases, India and Kilo, and they started with patrolling, escorting, guarding convoys, setting up check points, distribution of funding, reconstruction of schools, stadiums, kindergartens, police stations, wells, and other infrastructure in Karbala and the neighboring towns Ain Al Tamur, Al Forst, Al Hyndiya, and others. ${ }^{13}$

For most of the period of the first deployment, the Bulgarian mission in Iraq seemed free from serious accidents, compared with the other parts of Iraq, especially the capital, Baghdad, and Saddam's stronghold, Tikrit. Everyday life was far from being pastoral and easy - on the contrary, there almost daily there have been explosions, firing, and attempted raids - but without any casualties. With the time of the rotation

13 Most of the details described here are according to the $B A, 12$ February 2004, Nr. 15798. 
approaching, everything seemed to go exceptionally smoothly. ${ }^{14}$

On Christmas Eve, the Bulgarian battalion commander, Lt. Col. Petko Marinov, was recognized as "the officer of the year." Only a few days later, one of the two Bulgarian camps in Karbala, called India, suffered a suicide assault by a heavy truck loaded with explosives, which killed five Bulgarian soldiers and wounded many others, some of them heavily. Their military compound - a former school, hastily refurbished to serve its new purpose, and located in an area of heavy civilian traffic with a highway, a mosque, and a plant near-by - was completely destroyed and had to be abandoned. An investigation reported that, under the circumstances, Bulgarian troops has performed highly professionally, avoiding even greater tragedy, and no one was found to be guilty in any way for the occurrence. One thing, however, could be taken for granted: subsequent deployments would be much more thoroughly trained. The initial pre-deployment training of the first battalion for Iraq, in order to meet the deadlines, had been cut down to 186 hours, while for the second rotating battalion this period is 480 hours, and for the battalion currently undergoing preparation 550-600 hours are envisaged.

Providing for this training is entirely the responsibility of the civilian political leadership of the military, which failed to admit that its oversight was due to haste to promulgate its merits to the U.S. and NATO leadership. At this juncture it seems at least premature, if not cynical, to assert, as Minister Svinarov put it, that the Bulgarian contingent in Iraq has been "the best prepared among the whole coalition forces there." Public opinion, staggered by the unexpected arrival of the coffins of five young men on New Year's Eve, will never cease to ask many questions that are still unanswered. How was this event possible? Could it have been avoided? Was it not possible to find a more suitable and appropriate place for a military base, or at least to better fortify the camp? This debate certainly exceeded the scope of purely expert opinion, taking on somewhat theoretical dimensions. Civilian journalists latched on to the sensation, and wrote groundless and thrilling speculations, even trying to blame Polish commanders for allegedly sending Bulgarians into harm's way, or accusing allies of conspiring with local sheiks. Such contemplation led to unnecessary tension between the Polish command and the Bulgarian unit, and to an exchange of letters between the Bulgarian president and his Polish counterpart. Soldiers - both from the mission, and from units that have never been part of similar assignments - freely shared opinions to the media

14 An exception was a humorous case that proved the overall confusing situation in the postwar Iraq. The Mayor of Karbala came to Bulgaria on an official visit to negotiate cooperation and supplies, and he was received at a very high level for such a public servant, including by the Prime Minister and the President. Suddenly came the news that mayor had left his country inappropriately; he had been issued a new passport by the Ministry of Foreign Affairs (a university Professor, the mayor was prohibited from foreign travel by the Saddam regime), and departed normally, checking in at the Baghdad airport, but the U.S. occupational authorities had not been informed in order to issue formal permission. Then the Americans issued an order for the arrest of the mayor, which could put the Bulgarian authorities in quite an embarrassing situation, but the misunderstanding was relatively quickly solved. 
far beyond their competence. A captain said in an interview that it has been totally wrong to try to establish relations of trust and friendship with the local population; instead, "we ought to suppress them.... We saw that you can not trust an Arab." Such an attitude of hatred is, indeed, incompatible with a peacekeeping mission. Some complaints from members of the mission and their parents that soldiers sent there had not been prepared for the situation that they encountered on the ground also seem exaggerated. Indeed, one might reasonably expect that a mission on which each member receives, in addition to his or her salary, a daily allowance that is about the minimal monthly salary in Bulgaria, can not simply be a safe trip to an exotic place.

Lessons from the tragic incident cannot hide the generally positive outcomes from the first six months of the mission. As a whole, it could be described as an advantage to the Bulgarian peacekeepers asset that Karbala - a province with a population of 2.8 million people, with 700,000 in the city itself-remained for most of the time a relatively calm area, compared with most of the other parts of the country. Some complex situations arose during the Shiite religious festivals, which had been banned by the Sunni-dominated regime and involved the participation of a great quantity of pilgrims from other parts of the country and abroad, including from Iran, but they were handled quite smoothly. There have been no cases of abuse of the local population, even after the assault that understandably increased tension. Some 480 Iraqi volunteers have been trained to participate in the civilian defense corps, and a 4,500-strong Iraqi police force has started to perform its duties. In addition, water treatment stations, irrigation facilities, and an electricity supply facility have been built; eight schools and a kindergarten have been renovated; and an emergency room and an obstetrics clinic have been modernized, along with thirty-four other civilian buildings. As a whole, the three consequently deployed Bulgarian battalions in Karbala have completed 30 projects costing US\$2.5 million, according to the Bulgarian daily Standart on 9 November 2004.

The second battalion that replaced the first one after the end of its term took its positions of duty not only under the shadow of the sad event at the end of the preceding tour, but their beginning was also marred by other failures. Within two weeks after accepting his duties, the next commander, Lt.Col. N. Lyutskanov, was suddenly dismissed. The official reason given was his inability to communicate in English-he is fluent in French, instead of the main language in use among the allies. But such an important issue was hardly to have been kept concealed after months of initial preparation, examinations, and reviews of records. Rumors, however, reveal other causes: crude behavior toward subordinates, discourteous statements to the senior commander, poor oversight of relations with the Polish staff, and lack of organizational abilities. ${ }^{15}$

This new development revealed that the current Bulgarian military is not able to offer a large choice of suitable candidates for such complicated missions: only nine officers from a total of 4,000 in the Bulgarian Ground Forces are considered fit to command a battalion, but only two of them were enthusiastic enough to volunteer for the

15 It was even said that after learning about his removal - from a private Bulgarian TV channel that is received in the battalion, and not through formal channels- he has warned about possible mutiny among his troops. 
position in Iraq. One of the deputy commanders was appointed to fill the job, and his record reveals a high level of English language skill and expertise in military intelligence and staff work, but inadequate practice in leading of troops. This time, without any other explanation, the Bulgarian commander was appointed deputy military governor, while the principal position was given to a Polish officer. In the meantime, one soldier was wounded in a traffic accident, and another received a head injury after negligent manipulation of his weapon by a colleague. Again, military authorities in Sofia were perplexed by contradictory statements and attempts to deny the importance of the accidents. Happily, no serious incidents followed, with the exception of the killing of a soldier on patrol. However, ever increasing tensions - reaching the dimensions of a full-fledged civil war-can seriously endanger the completion of the mission in the future. In this same period, two Bulgarian civilian truck drivers were taken hostage and murdered, which amplified sentiment for the withdrawal of Bulgarian troops. In the beginning of November 2004, Bulgarian troops were successfully redeployed from the Kilo base in Karbala to the Echo camp in Diwaniya, Kadissiya province. This camp, site of an Iraqi armored brigade, which was used earlier by the withdrawn Spanish unit, is considered better equipped and safer. Upon leaving, a Karbala official expressed the opinion that Bulgarian troops have been accepted as friends and not as occupants. Sadly, the third Bulgarian battalion suffered one more loss during its mission.

Recent developments involving the Bulgarian elite forces sent to Iraq shed more light on the overall situation in the Bulgarian armed forces just at the moment when the country joined NATO. Heavy reductions of personnel have taken place - only at the end of 2003, another 1,000 qualified officers of various ranks submitted their resignations from the military, disappointed by the decision to increase by five years the length of service necessary for retirement. Measures like this led to meeting the planned estimates for the reduced size of the military, according to the famous "Plan 2004," but left whole segments without proper functional staff. Moreover, it once again became clear that the interaction between the civilian leadership of the Ministry of Defense and the General Staff is far from serenity and congruence. Again, some speculations about subordinating the General Staff under the civilian minister re-emerged, a proposition that pushes the entire scheme of reform backward. Military leaders seem reasonably angered by the fact that more than 5,000 bureaucrats employed by the ministry - a number almost twelve times larger than the personnel of the General Staff, which is engaged in the operative management of the troops - expends 25 percent of the defense budget, which exceeds the amount allocated to entire branches, such as the navy. In his turn, the Chief of the General Staff, General Kolev (himself an air force officer, who has spent all his career in staff work without guiding even a platoon), demanded that the department responsible for military intelligence be transferred from the ministry to the General Staff. And all this after the serious arguments about the failure of the military's investigation to establish well in advance a picture of the likely threats to the Bulgarian peacekeepers and to warn about these, thus doing nothing to prevent the tragedy; or after the chiefs there claim that they had prepared and submitted appropriate files about what could be expected, to find out why these recommendations never reached the commanders in Karbala. 
There is a Bulgarian proverb that says that, after the car has crashed, there are always many suggestions about how the accident could have been avoided. And another one: small pebbles can cause a car to crash. The tragic events that happened in Karbala with the Bulgarian contingent are not entirely extraordinary - it is a country at war, and we have military men and women that have made their own choice for a martial profession, which involves danger, even in peacetime. Other units deployed in Iraq-including, especially, the Americans - also suffer heavy casualties and losses in a war without a proper battlefield, where you can hardly recognize the enemy, where each seemingly innocent passer-by - even a child or a young woman - can carry a lethal load of explosives under their clothes. But only if the lessons from every minute of the assault there are well learned can similar cases be prevented - or, at the very least, the after effects could be brought to a minimum. Only in that way will there be a real, reasonable benefit for the future development of the Bulgarian military on peacekeeping missions like this in Iraq, instead of serving only as cannon fodder for an unclear cause. And, finally, this is the only way to prove that the victims of the assault in Karbala - among them some promising and well-trained young officers - have not died in vain. It is exactly what their superiors owe them, not simply the solemn and lavish ceremony that was arranged at the Central Military Hall in Sofia for a last farewell, one that could otherwise be seen as highly hypocritical.

The participation of the Bulgarian armed forces in peacekeeping and peace-enforcing operations is not a whimsical or a secondary activity, but a part of wellgrounded and deliberate policy. Moreover, as a senior Ministry of Defense official put it a short while ago, in the current strategic environment it is much more likely for the armed forces to be used within the frameworks of allied and coalition operations outside of Bulgaria than within its own borders. ${ }^{16}$ Such a prospect, indeed, does not mean any decline of the armed forces' readiness to meet whatever threat to the national security may arise; on the contrary, it is an indispensable part of a complex set of functions and tasks that are to be fulfilled together and in concert with other public bodies, institutions, and structures. But it has also some more immediate and practical effects, namely in the important fields of social policy and economy. These missions create or maintain jobs, because there are many more people involved in the process of preparation, support, and supply of them than just the direct participants. These missions revived productive activities of the army's departments of rear services in Kalofer, which prepared in short order new uniforms suitable for the deployment in Iraq (one that was appraised as among the best compared with those worn by other countries' troops there, and orders from abroad are currently under discussion). Some precision equipment, including tools for night vision, were procured from the otherwise doomed to cancellation Optikoelekton plant in Panagyurishte. Among other similar procurements could be mentioned bulletproof vests (although they have to be improved upon after complaints of their being heavier and awkward compared with similar foreign-made items) and also the re-equipment, adaptation, enhancement of protection, and re-arma-

16 “Middle-Range Priorities and Goals of Defense," BA, 10 November 2003, Nr. 15725. 
ment of the vehicles at the disposition of the contingents, including modification of the machinery contributed by the U.S. troops and those of other countries. These follow-up outcomes and effects, though supplementary, should not be disregarded when a complete account of the positive aspects of Bulgaria's participation in foreign peacekeeping missions is made. And, above all else, it is a source of new and useful experience that serves to further shape the new, modern image of the Bulgarian military. 
THE QUARTERLY JOURNAL

\section{Bibliography}

Angarev, Panayot. "Army - Reduced, but not Reformed." Dnevnik Daily (2002).

Ashley, Stephan. "Bulgaria: Between Loyalty and Nationalism." In The Warsaw Pact and the Balkans: Moscow's Southern Flank. New York: St. Martin's Press, 1989.

Behar, Nansen. "Civil-Military Relations and the New Defense and Security Legislation in Bulgaria." In Legal Framing of the Democratic Control of Armed Forces and the Security Sector: Norms and Reality/es. Geneva: DCAF, 2001.

Nelson, Daniel. "Political Dynamics and the Bulgarian Military." Berichte des Bundesinstituts für ostwissentschaftlisches und internationale Studien 43 (1990).

Nikolov, Stephan E.. "The Bulgarian Armed Forces in Transition." Jane's Intelligence Review (1995): 152-53. 